

\section{Constructing cybersecurity}

\section{MANCHESTER 1824}

Manchester University Press 
Andrew Whiting - 9781526123336 Downloaded from manchesterhive.com at ๑4/26/2023 ๑2:58: ๑९PM via free access 


\section{Constructing cybersecurity \\ Power, expertise and the internet security industry \\ Andrew Whiting}

Manchester University Press 
Copyright $($ ) Andrew Whiting 2020

The right of Andrew Whiting to be identified as the author of this work has been asserted by him in accordance with the Copyright, Designs and Patents Act 1988.

Published by Manchester University Press

Altrincham Street, Manchester Mi 7JA

www.manchesteruniversitypress.co.uk

British Library Cataloguing-in-Publication Data

A catalogue record for this book is available from the British Library

ISBN 978 I 526I 23329 hardback

First published 2020

The publisher has no responsibility for the persistence or accuracy of URLs for any external or third-party internet websites referred to in this book, and does not guarantee that any content on such websites is, or will remain, accurate or appropriate.

Typeset by Sunrise Setting Ltd, Brixham

Printed in Great Britain

by TJ International Ltd, Padstow 